Estudios Constitucionales, Año 13, No 1, 2015, pp. 237-270.

ISSN 07180195

Centro de Estudios Constitucionales de Chile Universidad de Talca

"La deferencia del Tribunal Constitucional respecto del juez de la gestión pendiente en la cuestión de inaplicabilidad"

José Ignacio Martínez Estay

\title{
LA DEFERENCIA DEL TRIBUNAL CONSTITUCIONAL RESPECTO DEL JUEZ DE LA GESTIÓN PENDIENTE EN LA CUESTIÓN DE INAPLICABILIDAD*
}

\author{
The Deference of the Constitutional Court to \\ INFERIOR COURTS IN INAPPLICABILITY CASES
}

\author{
José Ignacio MarTínez Estay* \\ Universidad de los Andes \\ jimartinez@uandes.cl
}

RESUMEN: Desde la reforma constitucional de 2005, la deferencia y auto-restricción del Tribunal Constitucional en el control de los poderes públicos es un supuesto no sólo respecto del legislador y del ejecutivo, sino que también de los jueces ordinarios y especiales, a raiz del modelo de inaplicabilidad consagrado en el artículo $93 N^{\circ} 6$ de la Constitución. La jurisprudencia del Tribunal Constitucional revela su esfuerzo por restringir el control a lo estrictamente necesario, y a procurar no asumir competencias y facultades que reconoce como propias del juez de la gestión pendiente. En el presente trabajo se revisarán los criterios de deferencia extraídos de dicha jurisprudencia.

ABSTRACT: Since the constitutional amendment of 2005, the deference and self-restriction of the Constitutional Court is not only a matter in his relationship with the legislator and the executive power, but with ordinary and special judges too. This is a consecuence of the new inapplicability enshrined in Article $93 N^{\circ} 6$ of the Constitution. The Constitutional Court's jurisprudence reveals the special effort to restrict their control to what is necessary, and try not to assume jurisdiction and powers of those judges. This paper analyze the deference criteria drawn from the Constitutional Court jurisprudence.

PalabRas CLAVE: Inaplicabilidad, Tribunal Constitucional, jueces, criterios de deferencia y autorrestricción.

KEY WORDS: Inapplicability, Constitutional Court, judges, deference and self restriction criteria.

\footnotetext{
* Trabajo recibido el 14 de marzo de 2015 y aprobado el 22 de abril de 2015.

** Profesor de Derecho Constitucional y Administrativo, Facultad de Derecho, Universidad de los Andes, Chile. Este artículo recoge parte de los resultados del proyecto Fondecyt No 1120634, "Auto restricción y deferencia razonada: Límites al escrutinio de la actividad legislativa, administrativa y judicial en el Tribunal Constitucional chileno" del que el autor es investigador responsable. El punto II. del presente trabajo recoge parte de la información contenida en otro anterior del autor, MarTínez (2011), pp. 377-396. Mis agradecimientos a mi ayudante de investigación, Federico Ignacio Espinosa Fernández, por su incansable trabajo de búsqueda, recopilación y sistematización de la jurisprudencia aquí presentada, y por su ayuda en la preparación del primer borrador de este trabajo.
} 


\section{Presentación}

Este trabajo es una continuación del titulado "Auto-restricción, deferencia y margen de apreciación. Breve análisis de sus orígenes y de su desarrollo"1, y se centra en la forma en que el Tribunal Constitucional (TC) se relaciona con el juez de la gestión pendiente en materia de inaplicabilidad. Más precisamente, se analizará cómo el TC deja a salvo las competencias del juez ordinario o especial ante el que se sigue el asunto en que incide su control, a partir de lo cual se procurará identificar criterios específicos extraídos de su jurisprudencia.

Como se sabe, la deferencia y el margen de apreciación que debe observar el Tribunal Constitucional (TC) en su rol de controlador de la actuación de los poderes públicos, es una consecuencia directa del principio de juridicidad, y de la idea de que "los órganos del Estado actúan válidamente, previa investidura regular de sus integrantes, dentro de sus competencias y en la forma que prescriba la ley" (artículo 7o de la Constitución). Ello implica reconocer que existen órbitas o ámbitos de actuación que son de competencia de otros órganos públicos, y en tal sentido la deferencia implica la necesidad de que el TC respete las legítimas decisiones que, en el ámbito de sus competencias, adopten los poderes sujetos a aquel control ${ }^{2}$.

A partir de la reforma constitucional de 2005, la deferencia pasó a ser un supuesto de las relaciones del TC no sólo con el legislador y el ejecutivo, sino que además con los jueces ordinarios y especiales. Ello se debe a que la cuestión de inaplicabilidad del artículo 93 No 6 de la Constitución, implica el pronunciamiento del TC respecto de los posibles efectos inconstitucionales derivados de la aplicación de un precepto legal en una gestión judicial seguida ante un tribunal ordinario o especial 3 .

Esto constituye un enorme desafío para el control judicial, el que en ningún caso puede servir de excusa para la intromisión de los jueces constitucionales en materias que no son de su competencia, y evitar por ende el activismo judicial, o la sustitución de decisiones meramente políticas o técnicas por sentencias. Pero

\footnotetext{
1 MarTínez (2014), pp. 365-396, trabajo que también se enmarca en el proyecto Fondecyt No 1120634.

2 Como señala Zapata, la deferencia supone "de cada órgano del Estado el reconocimiento y respeto de las esferas competenciales en que las autoridades tienen el derecho a tomar decisiones con relativa autonomía” ZaPATA (2008), p. 227.

3 Un interesante análisis acerca de las consecuencias y desafíos que ha supuesto el actual mecanismo de inaplicabilidad puede consultarse en Couso y CodDou (2010), pp. 389-430.
} 
además de su relación con el principio de juridicidad, la deferencia y el margen de apreciación hacia el juez de la gestión se vincula también con el derecho al juez natural (artículo 19 No 3, inciso $5^{\circ}$ de la Constitución), y por ende supone que el mismo tribunal ante quien se trabó la litis, sea el que falle el asunto sometido a su decisión.

En consonancia con lo señalado, y según se podrá apreciar a continuación, la jurisprudencia del TC revela el gran respeto que éste ha observado respecto de los jueces de las gestiones pendientes en que inciden cuestiones de inaplicabilidad. Ello ha llevado al TC a restringir su control a lo estrictamente necesario, y a procurar no asumir competencias y facultades que reconoce como propias del juez de la gestión pendiente.

Por tanto en la inaplicabilidad la deferencia implica la autonomía de los tribunales que conocen de esa gestión para interpretar y aplicar el Derecho en la resolución de los conflictos sometidos a ellos, pero actuando en estas materias

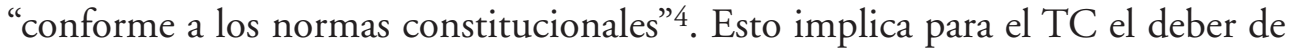
no sustituir la labor del juez ordinario ${ }^{5}$. No obstante, la actual inaplicabilidad ha sido concebida como un mecanismo de control de la aplicación de preceptos legales, ello implica necesariamente que el modelo conlleva un problema no menor. En efecto, la aplicación de un precepto exige interpretarlo, lo que a su vez plantea otra dificultad, a saber, hasta dónde puede llegar el TC sin invadir las competencias propias del juez de la gestión pendiente.

Si bien la deferencia es un criterio comúnmente utilizado por el TC a la hora de controlar las actuaciones del legislador, y en menor medida del ejecutivo, la evidencia indica que se ha ido incorporando cada vez más como criterio de delimitación de su control de inaplicabilidad. Ello es natural, ya que parte importante del trabajo que lleva a cabo el TC se concreta precisamente en procedimientos de inaplicabilidad, lo que le ha llevado a tener que extremar sus cuidados para no invadir competencias privativas del juez de la gestión pendiente.

$\mathrm{El}$ análisis de la jurisprudencia demuestra que el TC procura habitualmente discernir si con un requerimiento de inaplicabilidad se persigue realmente determinar si un precepto legal es o no constitucional, o si por el contrario lo que se pretende es impugnar cuestiones ya previamente resueltas por el juez de fondo, o imponerle a éste la aplicación o no de una determinada normal legal. Ello le

4 Hormazábal (2006), p. 36.

5 Ver Aldunate (2009), pp. 11-12; también ZúNiga (2010), pp. 176-181. 
ha llevado a elaborar criterios destinados a velar por el respeto a las competencias del tribunal ante el cual se sustancia la gestión pendiente, y que todo operador jurídico debe considerar a la hora de plantear una cuestión de inaplicabilidad. Con esos criterios el TC busca evitar que las inaplicabilidades se transformen en una vía paralela de resolución de conflictos, omitiendo así el pronunciamiento que deba emanar del juez de fondo.

En resumen, son dos los objetivos que se persiguen con este trabajo. El principal será presentar un listado de los criterios de deferencia que el TC ha observado respecto del juez de la gestión pendiente. Estos criterios han sido recogidos de la jurisprudencia del TC, y su adecuada comprensión y conocimiento debiera ser de utilidad para los diversos operadores jurídicos, en particular jueces y abogados. El análisis jurisprudencial abarca hasta enero de 2015.

Junto a lo anterior, y aún antes de proponer el mencionado listado de criterios, el trabajo se hace cargo de la evidente dificultad que implica para el TC el control de la aplicación de preceptos legales, ya que aplicar una norma supone su previa interpretación. Por tanto, de la cuestión de inaplicabilidad se desprende la pregunta acerca de si el TC debe o no controlar la interpretación de dichos preceptos, lo que se procurará responder a continuación, antes de proponer y revisar los mencionados criterios de deferencia.

\section{El PROBLEMA DE LA INAPLICABILIDAD COMO MECANISMO DE CONTROL}

DE LA INTERPRETACIÓN/APLICACIÓN DE PRECEPTOS LEGALES

\section{A) La aplicación de un precepto legal implica necesariamente su interpretación}

Como se señaló en la presentación, una de las principales novedades de la reforma constitucional No 20.050 de 2005, fue el cambio experimentado por el recurso de inaplicabilidad. La nueva formulación del recurso de inaplicabilidad introduce un factor que en el anterior sistema no existía, y cuyas consecuencias son de enorme relevancia práctica. En efecto, cuando la Constitución exige ahora que la aplicación del precepto legal resulte contraria a la Constitución, obliga a su vez a perder de vista que todo acto de aplicación de una norma importa la interpretación de ésta 6 .

${ }^{6}$ En el texto original de la Constitución, de acuerdo al antiguo artículo 80, la inaplicabilidad era de competencia de la Corte Suprema, que decía: "Artículo 80. La Corte Suprema, de oficio o a petición de 
Parafraseando a Betti, la aplicación de las normas jurídicas requiere de una operación intelectiva llamada interpretación 7 , lo que en palabras de Zapata Larraín implica que "las normas jurídicas, igual que las obras de arte, deben ser interpretadas" 8 . Y es que, como señala Kelsen, la interpretación de la ley supone "saber cómo, aplicando una norma general a un hecho concreto, el órgano judicial o administrativo obtiene la norma individual que le incumbe establecer" . Ello porque "más allá de las intenciones, sin embargo, e independientemente del tiempo y talento invertidos en producir normas claras y unívocas, la verdad es que muchas normas jurídicas admiten más de una lectura"10.

Es por todo eso que a la hora de determinar lo justo para el caso concreto mediante la aplicación de la ley, el juez no sólo la aplica, sino que, como parte del proceso mismo de aplicación, la debe interpretar. Porque "cuando un juez aplica un precepto legal a un caso concreto, previamente lo ha de interpretar. No puede haber aplicación sin una previa interpretación"11. Y como la inaplicabilidad implica un juicio de constitucionalidad sobre la aplicación del precepto legal al caso concreto, ello conlleva necesariamente un enjuiciamiento de la interpretación de la norma.

Como sostuvo el ex Ministro Correa Sutil en su voto concurrente de la sentencia rol No 810, "es físicamente imposible que una ley pueda producir, por sí sola, un efecto contrario a la Constitución en una gestión determinada que se siga ante un tribunal ordinario o especial. Siempre que el precepto legal produzca efectos en un caso, lo será porque el juez le ha dado aplicación y para darle aplicación debe fijar su sentido y alcance. En razón de ello, cuando el efecto contrario a la Carta Fundamental es producido por la interpretación del juez, esta Magistratura igualmente debe conocer. Si bien se trata de un problema de interpretación legal, que corresponde resolver a los jueces de la instancia, es el

parte, en las materias de que conozca, o que le fueren sometidas en recurso interpuesto en cualquier gestión que se siga ante otro tribunal, podrá declarar inaplicable para esos casos particulares todo precepto legal contrario a la Constitución. Este recurso podrá deducirse en cualquier estado de la gestión, pudiendo ordenar la Corte la suspensión del procedimiento".

7 Beтtт (2009), p. 72.

8 Zapata (2008), p. 140.

9 Kelsen (1973), p. 163.

10 ZAPATA (2008), p. 145.

11 Hormazábal (2006), p. 36. 
precepto legal, aplicado en una de sus posibles inteligencias, el que -según la parte- produce efectos contrarios a la Carta Fundamental. Los preceptos legales que los jueces deben interpretar y aplicar, se formulan a través de un lenguaje y ese lenguaje no significa nada si no es para quien lo descifra, para quien fija su sentido y alcance, usando para ello las convenciones propias de la semántica y sintáctica del idioma respectivo y recurriendo a los demás elementos de interpretación. Si un juez fija un sentido y alcance razonable y posible de un precepto legal y, aplicado en ese sentido el precepto legal al caso, produce efectos contrarios a la Carta Fundamental, es deber de esta Magistratura evitarlo. Tal deber no puede eludirse en razón de que el efecto inconstitucional no está en la ley, sino en la interpretación, pues, como se ha demostrado, nunca el efecto va a ser producido por la ley al margen del juez y siempre y necesariamente el efecto va a radicar en el modo en que el precepto se entienda y aplique al caso" (considerando $3^{\circ}$ de su voto concurrente).

Es interesante considerar que este enjuiciamiento puede ser hecho por el Tribunal Constitucional no sólo mientras esté pendiente la dictación de sentencia definitiva, sino que incluso estando pendiente la revisión de ésta, por ejemplo en sede de apelación. Es decir, el asunto ha sido ya resuelto por un tribunal, en contra de cuya decisión se recurrió por una de las partes, y habiéndose iniciado el conocimiento del recurso, el propio recurrente o el tribunal que conoce del recurso, plantea la cuestión. Y como se comprenderá, habiendo existido ya pronunciamiento judicial previo, es evidente que la cuestión puede decir relación precisamente con la forma en que se interpretó, y por ende la manera en que se aplicó un precepto legal. En otros términos, en este supuesto la cuestión de inaplicabilidad se transforma en un mecanismo de control de la interpretación/ aplicación de una norma legal en un caso concreto. En palabras de Gómez Bernales, "la inaplicabilidad... funciona como control de interpretaciones o significados de los enunciados (normas) aplicables a casos"12. De ahí que lo que en verdad resulta inaplicable "es la o las interpretaciones o significados de ese enunciado que el juez o la parte consideran inconstitucionales en la específica aplicación de dicha norma al caso". ${ }^{13}$

12 Gómez (2005), p. 669.

13 Ibid. 


\section{B) Diversos supuestos de control de la interpretación de un precepto legal}

Como se dijo, la inaplicabilidad implica en último término un mecanismo de control de constitucionalidad de las interpretaciones, que conduce a aplicar preceptos legales de determinada manera en casos concretos. Si la redacción de la norma es abiertamente inconstitucional, es probable que la interpretación de aquélla también lo sea, pues muchas veces el intérprete se ciñe a la literalidad de la norma que interpreta. Pero hay varios casos en que aquello no sucede. Y es que como señaló el ex Ministro Correa Sutil en el voto concurrente mencionado precedentemente, "ocurre con mucha frecuencia que el sentido de una norma no está contenido de manera evidente en su tenor literal" (sentencia rol No 810, considerando 5 de su voto concurrente). Ello se traduce en una serie de supuestos que conducen a la constitucionalidad o a la inconstitucionalidad de la norma. Entre éstos pueden indentificarse al menos los siguientes:

1. El precepto es constitucional desde el punto de vista literal, por lo que en principio su interpretación y consecuente aplicación no es contraria a la Constitución, pero ha sido interpretado y aplicado de una manera que resulta inconstitucional. Este supuesto se presentará en aquellos casos en que ha habido una gestión en la que un juez ya aplicó la norma legal. En este caso, dicha interpretación puede ser objeto de control vía inaplicabilidad, en la medida que exista aún gestión pendiente, lo que ocurrirá si se interpusieron los recursos procesales que procedieren en contra de aquella decisión. En tal caso, la cuestión de inaplicabilidad operará como un control represivo respecto de la aplicación que se hizo del precepto.

2. El precepto legal admite diversas interpretaciones, y puede ser considerado constitucional si se interpreta de una manera que permita una aplicación acorde a la Constitución. Tal es el caso de la norma cuya redacción no conduce necesariamente a una aplicación inconstitucional, a menos que el intérprete sí le dé un sentido y alcance contrario a la Constitución. Este supuesto se presenta en aquellos casos en que hay una gestión en la que aún no se ha aplicado el precepto legal, como en los que sí se ha aplicado, aunque está pendiente aún la resolución de recursos procesales. En este caso la cuestión funciona como un instrumento de control preventivo, en el sentido de que permitirá que el precepto legal se aplique sólo si aquello es conforme a la Constitución. En estos supuestos el TC controlará las diversas interpretaciones posibles que puedan dársele a un precepto legal, pero sólo a fin de descartar aquéllas que puedan ser opuestas a la 
Constitución. Es lo que hace a través de lo que el TC denomina "interpretación conforme", que se ha transformado en una especie de parámetro general para su control de constitucionalidad, y que es una consecuencia directa de la deferencia que le debe al legislador ${ }^{14}$.

Es evidente que todo esto genera una situación compleja, propia de nuestro modelo de control de constitucionalidad, que ha sido bien reflejado por Gómez Bernales, a propósito de las cuestiones de inaplicabilidad planteadas por las partes de la gestión. Ello porque si la cuestión se plantea habiéndose ya dictado sentencia "por un juez de fondo, es inevitable que el TC se pronuncie respecto de la sentencia al decidir si el precepto legal con arreglo al cual se decidió por el juez el litigio es inaplicable al caso. En tal sentido, indirectamente el juez constitucional cuestionará la negligencia del juez de fondo de no advertir o dudar de la constitucionalidad del precepto que utilizó para decidir" 15 .

El problema está en que aquello debe ocurrir en un marco de separación de funciones, que conforme al artículo $7^{\circ}$ de la Constitución implica que los órganos del Estado deben actuar "dentro de su competencia". Y como se comprenderá, el actual modelo de inaplicabilidad supone el riesgo de que el control conduzca a una invasión de las competencias propias de los tribunales ordinarios o especiales por parte del TC. Sin embargo, y como se verá a continuación, las sentencias de inaplicabilidad demuestran con cierta claridad que el TC ha procurado actuar con enorme deferencia al ejercer dicho control. Y si bien ello resulta complejo, ya que la inaplicabilidad implica eventualmente controlar la interpretación de preceptos legales, el TC ha elaborado una serie de criterios respecto de su propia competencia en materia de inaplicabilidad, a fin de resguardar la competencia de los tribunales de la gestión pendiente.

\section{C) El Tribunal Constitucional y el control de la interpretación de un precepto legal en la cuestión de inaplicabilidad}

Una premisa básica del control de constitucionalidad vía inaplicabilidad es la expresada por el Tribunal Constitucional en la sentencia rol No 596-06, en

\footnotetext{
14 Sobre la "interpretación conforme" como criterio de deferencia hacia el legislador por parte del Tribunal Constitucional ver MARTínez (2014), pp. 365-396 (en especial pp. 385-387).

15 Gómez (2005), p. 677. Gómez advierte que este problema se plantea específicamente en las cuestiones deducidas por las partes y no cuando tienen su origen en el juez, pues en este caso "la pregunta central será si el criterio del juez esbozado acerca de cuál es el precepto que decide el caso y por qué es inconstitucional obliga al TC a circunscribirse a esa perspectiva o puede adoptar otra". Ibíd.
} 
la que se señala que su objetivo no es resolver en abstracto si un precepto legal es o no acorde a la Constitución, sino que determinar si su aplicación se ajusta a la Carta Fundamental en un caso concreto (considerando $12^{\circ}$ ). Esto es sin perjuicio de que, "para realizar el referido juicio de constitucionalidad basta que el juez que conoce de la gestión pendiente tenga la posibilidad de aplicar dicho precepto en la decisión que ha de adoptar y que, al hacerlo, pueda vulnerarse la Constitución, independientemente de que existan otros preceptos legales que también pueda considerar, los que deben estar asimismo indiscutiblemente subordinados a la Ley Fundamental" (sentencia rol No 634-06, considerando 80).

En complemento de esas afirmaciones, en la sentencia rol No 806-07 el TC enfatizó que, "a este Tribunal no le compete ordenar que una causa sea conocida o resuelta conforme a determinados preceptos legales, lo que es propio de los jueces del fondo, sino evitar la aplicación de preceptos legales que puedan producir efectos inconstitucionales" (considerando $5^{\circ}$ ). Y en tal sentido sí "es deber de esta Magistratura evitar que el precepto legal impugnado se interprete y aplique de un modo en que efectivamente produzca un efecto contrario a la Constitución" (considerando $32^{\circ}$ de la misma sentencia) ${ }^{16}$.

Ese mismo criterio fue reiterado por el Tribunal en su sentencia rol No 1390 09, en que señaló que: "no coincide con la naturaleza y finalidad de la inaplicabilidad invocar una serie de disposiciones legales, de las cuales las dos primeras adolecerían de inconstitucionalidad, pero no las dos restantes, salvo que el intérprete vincule a las cuatro normas y las interprete asociadas en términos de asignarles sentido y alcance contrario a la Constitución" (considerando $11^{\circ}$ ).

Por lo mismo, como la aplicación supone previa y necesariamente la interpretación del precepto legal, parece claro que el TC puede controlar la constitucionalidad de una interpretación que ya ha sido dada por un órgano judicial en cualquiera de los supuestos recién mencionados. En tal caso la labor del juez constitucional se traduce en dictar lo que Zapata Larraín denomina una "sentencia interpretativa”, que es aquella mediante la cual el Tribunal Constitucional "identifica en sus sentencias la interpretación constitucionalmente aceptable de una norma legal"17. Este mecanismo ha sido utilizado en reiteradas oportunidades por el Tribunal Constitucional, y es de habitual aplicación por órganos

16 Estos mismos términos son reproducidos en la sentencia rol No 993 de 13 de mayo de 2008, considerando $5^{\circ}$.

17 ZAPATA (2008), p. 326. 
similares de otros países del mundo ${ }^{18}$. Mediante la dictación de una sentencia interpretativa, una norma será constitucional si se interpreta conforme a lo que al respecto señale el Tribunal. Y como destaca el propio Zapata, esta forma de control resulta ajustada a la doctrina de la "presunción de constitucionalidad de los actos del legislador", y a la "deferencia razonada"19, pero a su vez permite velar por la supremacía de la Constitución.

Si bien este mecanismo tradicionalmente ha sido utilizado por el Tribunal Constitucional al ejercer control abstracto, ello no debe ser impedimento para su aplicación en materia de inaplicabilidad. Esto por al menos las siguientes razones:

1. Porque la lógica del control concreto de constitucionalidad debe basarse en los mismos principios sobre los que descansa también el abstracto: supremacía de la Constitución ${ }^{20}$, presunción de constitucionalidad de los actos del legislador, y deferencia razonada ${ }^{21}$.

2. Porque incluso de manera más evidente que en el control abstracto, en el caso de la inaplicabilidad lo que se controla es la interpretación de una norma. Ello porque, como se dijo antes, la aplicación de un precepto supone necesariamente su interpretación. De ahí entonces que la sentencia que recaiga en la inaplicabilidad será siempre interpretativa.

3. Porque en la inaplicabilidad el principio de deferencia razonada debe hacerse extensivo no sólo respecto del legislador, sino que además del juez de la instancia. Ello implica que en las relaciones entre los jueces ordinarios y especiales y el TC,

18 Como señala Favoreu, "las jurisdicciones alemana, italiana, austríaca y francesa tienden a poner a punto técnicas que permitan controlar la legislación sin entrar en colisión frontal con el legislador. Más que pura y simplemente anular, el juez constitucional prefiere declarar conformes sus reservas,...”. En FAVOREU (1994).

19 ZAPATA (2008), p. 327.

20 A este respecto en la sentencia rol No 634-06, el TC hizo presente que, "la necesidad de velar por el pleno respeto del principio de supremacía constitucional que persigue la declaración de inaplicabilidad de un precepto legal determinado en cualquier gestión que se siga ante un tribunal ordinario o especial, obliga a esta Magistratura a examinar si el precepto legal que se encuentra vigente y que se ha impugnado a través de la acción deducida, podría resultar contrario a la Carta Fundamental en su aplicación al caso concreto examinado" (considerando $8^{\circ}$; el destacado es nuestro). En este mismo sentido se pronuncian las sentencias roles $810-07$, considerando $9^{\circ}$, y 968 , considerando $15^{\circ}$.

21 Si bien la sentencia interpretativa ha sido utilizada tradicionalmente en el ámbito del control abstracto, no se ve por qué no pueda ser ocupada en el marco del control concreto. Ello por dos razones. En primer lugar porque, como ya se dijo, no hay nada que impida que el Tribunal Constitucional al ejercer control de inaplicabilidad interprete el precepto objeto de control. Y en segundo lugar, porque precisamente como el Tribunal tiene esta facultad, debe ejercerla respetando el principio de deferencia razonada. 
este último debe respetar la autonomía de los primeros para interpretar y aplicar el Derecho en la resolución de los conflictos sometidos a ellos, siempre y cuando actúen "conforme a los normas constitucionales" 22.

4. Porque, como ha señalado el ex Ministro del Tribunal Constitucional Sr. Bertelsen, "es deber del intérprete preferir, entre dos interpretaciones posibles, la que resulta más conforme a la Carta Fundamental. Así lo exige el principio de supremacía constitucional y asimismo el criterio sistemático de interpretación de las leyes. De ahí que al escoger un tribunal la que se aparta de ella, efectúa una aplicación de la ley que resulta contraria a la Constitución y que hace procedente acoger el recurso de inaplicabilidad interpuesto" (sentencia rol No 810 , considerando $7^{\circ}$ de su voto de minoría).

En todo caso, es importante destacar que todo ello sólo implica la posibilidad que tiene el TC de descartar la aplicación de aquellas interpretaciones que pudieran ser contrarias a la Constitución. Pero en ningún caso puede suponer una competencia de éste para determinar cuál de las diversas interpretaciones posibles y ajustadas a la Constitución, es la que se debe aplicar el juez de la gestión pendiente, según se verá más adelante.

\section{D) Algunos ejemplos de control de constitucionalidad de interpretaciones de preceptos legales}

En la jurisprudencia del TC es posible encontrar casos en que éste ha aplicado la doctrina enunciada precedentemente, y por ende ha controlado la constitucionalidad de las posibles interpretaciones de preceptos legales aplicables a un caso concreto. Así por ejemplo, en la sentencia rol No 478-06, el TC resolvió una cuestión de inaplicabilidad respecto del inciso $3^{\circ}$ del artículo 416 del Código Procesal Penal ${ }^{23}$, en el contexto de un procedimiento de desafuero en contra de un parlamentario seguido ante la Corte de Apelaciones de Santiago. En la cuestión se planteó que dicho precepto podría ser inconstitucional, en la medida que se interpretase en el sentido de que en los delitos de acción privada, la Corte de Apelaciones debe pronunciarse acerca del desafuero con el solo mérito de la querella. Ello porque, a juicio del recurrente, se vulneraría el racional y

\footnotetext{
22 Hormazábal (2006), p. 36.

23 El artículo 416 inciso $3^{\circ}$ del Código Procesal Penal señala que: "Si se tratare de un delito de acción privada, el querellante deberá ocurrir ante la Corte de Apelaciones solicitando igual declaración, antes de que se admitiere a tramitación su querella por el juez de garantía”.
} 
justo procedimiento consagrado en el inciso quinto del artículo 19 No 3 de la Constitución, lo que haría ilusoria la institución del fuero parlamentario, al no permitir la práctica de diligencias probatorias, vulnerándose así además el artículo 61 de la Constitución.

Al respecto el Tribunal sostuvo que el artículo 93 No 6 de la Constitución, "revela que la magistratura constitucional no está compelida a la mera comparación abstracta de dos normas de diverso rango, para desentrañar su incompatibilidad" (considerando 15). Por eso el Tribunal afirmó que su rol pasa por determinar si efectivamente, "en la gestión pendiente, la aplicación del precepto impugnado puede producir efectos contrarios a la Constitución. Ello puede ocurrir en la medida que, en la gestión pendiente, existan hechos pertinentes, sustanciales y controvertidos y que se entienda que el precepto impide la práctica de diligencias probatorias o la recepción de pruebas que el Tribunal juzgue como necesarias para resolver si ha o no lugar a la formación de causa en contra del diputado" (considerando 31\%).

El TC entendió que como no podía determinarse que en la gestión pendiente se verificasen efectivamente aquellas dos circunstancias, era su deber "evitar que el precepto legal impugnado se interprete y aplique de un modo en que efectivamente produzca un efecto contrario a la Constitución" (considerando $32^{\circ}$ ).

En razón de todo lo anterior, el TC entró derechamente a señalar qué sentido de la norma podría ser inconstitucional, o sea, cuál interpretación sería contraria a la Constitución. En concreto, sostuvo que: "conforme a todo lo razonado, debe entenderse que lo dispuesto en el inciso tercero del artículo 416 del Código Procesal Penal podría producir efectos contrarios a la garantía de un justo y racional procedimiento establecida en la Constitución, sólo si se le aplica en el proceso de desafuero entendiendo que el precepto impide producir, decretar o recibir prueba pertinente, aunque haya asuntos sustanciales y controvertidos para declarar si ha o no lugar a la formación de causa en contra del diputado ... y sólo en ese sentido se declarará que el precepto es inaplicable" (considerando 330 ${ }^{24}$.

24 Otros casos similares a los objeto de esta sentencia, y resueltos de manera parecida, son por ejemplo las sentencias roles $\mathrm{No}^{\mathrm{o}}$. 596 de 12 de julio de 2007, considerandos $6^{\circ}$ y 7o; 473, de 8 de mayo de 2007 , considerandos 6 al 12; 517, de 8 de mayo de 2007, considerandos $7^{\circ}$ al 13; 535 de 8 de mayo de 2007, considerandos $7^{\circ}$ al $13^{\circ}$, y 806, de 11 de diciembre de 2007, considerandos $5^{\circ}$ y ss.; 993 de 3 de mayo de 2008, considerando 50; 967 de 19 de diciembre de 2007, considerando 13; 791, de 15 de enero de 2008, considerando 26. 
Por su parte en la sentencia rol No 993-07, el Tribunal debió resolver una cuestión de inaplicabilidad respecto del artículo $4^{\circ}$ de la Ley № $20.000^{25}$, por considerar el recurrente que la norma en cuestión violaba el derecho a la presunción de inocencia. A juicio del requirente la norma impugnada contempla una presunción de responsabilidad penal que altera la carga de la prueba, al obligar a probar su inocencia a aquél en cuyo poder se encontrasen cantidades mínimas de droga. En su opinión ello implicaba una vulneración al debido proceso, el que incluye el derecho a la presunción de inocencia como componente esencial, y que constituye un derecho esencial que emana de la naturaleza humana. De acuerdo a este derecho, es al Estado a quien le corresponde probar la culpabilidad.

El TC señaló además que, "dentro del criterio de interpretación conforme a la Constitución, el respeto hacia las labores que desarrollan tanto el legislador al elaborar las normas de rango legislativo como la judicatura al aplicarlas, obliga al Tribunal Constitucional, en su función de contralor de la constitucionalidad de la ley, a buscar, al menos, alguna interpretación del precepto cuestionado que permita armonizarlo con la Carta Fundamental, y sólo en el evento de no ser ello posible, declarar su inconstitucionalidad, criterio que ha sido seguido en las sentencias roles $\mathrm{N}^{\circ}$ s. 29, 38, 304, 368, 420, 460 y 681, entre otras". Pero lo que es más importante, sostuvo que dicho criterio (interpretación conforme/sentencia interpretativa) resulta plenamente aplicable "en sede de inaplicabilidad", y que "también, en el caso concreto, 'es deber de esta Magistratura evitar que el precepto legal impugnado se interprete y aplique de un modo en que efectivamente produzca un efecto contrario a la Constitución' (Sentencia rol No 806)" (considerando $5^{\circ}$ ). Y precisando aún más su posición, hizo presente que "todo precepto legal que se impugne no constituye generalmente una norma aislada, sino que es

25 La norma impugnada señala que "[E]l que, sin la competente autorización posea, transporte, guarde o porte consigo pequeñas cantidades de sustancias o drogas estupefacientes o sicotrópicas, productoras de dependencia física o síquica, o de materias primas que sirvan para obtenerlas, sea que se trate de las indicadas en los incisos primero o segundo del artículo $1^{\circ}$, será castigado con presidio menor en sus grados medio a máximo y multa de diez a cuarenta unidades tributarias mensuales, a menos que justifique que están destinadas a la atención de un tratamiento médico o a su uso o consumo personal exclusivo y próximo en el tiempo. En igual pena incurrirá el que adquiera, transfiera, suministre o facilite a cualquier título pequeñas cantidades de estas sustancias, drogas o materias primas, con el objetivo de que sean consumidas o usadas por otro. Se entenderá que no concurre la circunstancia de uso o consumo personal exclusivo y próximo en el tiempo, cuando la calidad o pureza de la droga poseída, transportada, guardada o portada no permita racionalmente suponer que está destinada al uso o consumo descrito o cuando las circunstancias de la posesión, transporte, guarda o porte sean indiciarias del propósito de traficar a cualquier título". 
un enunciado que, puesto en aplicación, guarda relaciones de interdependencia y operatividad con otros, a la luz de los cuales cabe ser interpretado y aplicado" (considerando $6^{\circ}$ ).

No obstante, el TC rechazó la solicitud de inaplicabilidad, en atención a que la conducta que se sancionaba en la norma impugnada, "es la tenencia de las drogas prohibidas no destinadas al uso o consumo personal o con el propósito de traficar a cualquier título, quedando patente el bien jurídico protegido. En consecuencia, se trata de una peligrosidad concreta y que, por ende, debe ser acreditada en el proceso" (considerando $10^{\circ}$ ). En otros términos, el Tribunal entendió que el sentido de la norma no era establecer una presunción respecto de quien posee drogas para su consumo propio, sino que la tenencia para el tráfico debe ser probada. Por ende resultaba "posible entender y aplicar el precepto antes transcrito de conformidad a la Carta Fundamental, y por otra, no resulta dable concluir que exista una inversión de la carga de la prueba ni un atropello al debido proceso, pues, de todas formas y no habiendo norma en contrario, debe probarse, más allá de toda duda razonable, la comisión del hecho punible y la participación culpable del requirente, sin lo cual no puede ser condenado" (considerando $1^{\circ}$ ).

\section{Criterios de deferencia del Tribunal Constitucional HACIA EL JUEZ DE LA GESTIÓN}

Del estudio de la jurisprudencia del TC, es posible observar distintos criterios a través de los cuales éste manifiesta cierta deferencia respecto del juez de la gestión pendiente, a fin de evitar pronunciamientos que puedan predeterminar la decisión que este último debe adoptar en definitiva. Ello sin perjuicio de que, como se vio antes, el TC controla la interpretación de preceptos legales a través de la denominada "interpretación conforme". Pero como se verá a continuación, al hacerlo debe ser deferente y por ende respetar las competencias propias de los jueces ordinarios o especiales.

La revisión de la jurisprudencia del TC permite extraer los siguientes criterios de deferencia que aplica respecto del juez ordinario o especial:

\section{A) La "interpretación conforme" sólo se restringe a descartar interpretaciones inconstitucionales}

Como ya se adelantó, la forma en que el TC puede ejercer control de la interpretación de preceptos legales en casos concretos es a través de lo que el propio 
Tribunal denomina "interpretación conforme", que no es sino una consecuencia del "principio de auto restricción" o de "deferencia razonada". Ello implica el debido cuidado que el TC debe tener a efectos de no sustituir la labor del juez ordinario ${ }^{26}$.

Si bien históricamente la interpretación conforme ha sido utilizada en los procedimientos de control abstracto, el Tribunal la ha usado también en sede de inaplicabilidad. En palabras del ex Ministro del Tribunal Sr. Correa Sutil, el Tribunal Constitucional "en múltiples sentencias de control preventivo, ha reconocido que un precepto legal puede ser entendido en más de un sentido y lo ha aprobado en un determinado entendido, decidiendo que otros entendidos o sentidos posibles del precepto pugnan con la Constitución. Más precisamente en algunos fallos de inaplicabilidad, ha prohibido aplicar un precepto legal con un determinado alcance, sentido o interpretación que resultaría contrario a la Carta Fundamental o ha permitido su aplicación en el entendido o supuesto de que se le entenderá de un modo determinado" (sentencia rol No 810-07, considerando $6^{\circ}$ de su voto concurrente).

Así, en la sentencia rol No 480-06 el Tribunal ya había sostenido que en sede de inaplicabilidad debe analizar en el caso concreto si el precepto legal ha sido "correctamente interpretado" (considerando 27\%). Más tarde, en la sentencia rol No 806-07, sostuvo que: "no le compete ordenar que una causa sea conocida o resuelta conforme a determinados preceptos legales, lo que es propio de los jueces del fondo, sino evitar la aplicación de preceptos legales que puedan producir efectos inconstitucionales" (considerando 50). A su juicio, la determinación de si un precepto legal puede producir efectos contrarios a la Constitución dependerá entre otras cosas del "modo cómo se entienda, interprete y aplique el precepto. Esos dos aspectos contingentes deben ser entonces examinados" (considerando $27^{\circ}$ ). Y en tal sentido es su deber "evitar que el precepto legal impugnado se interprete y aplique de un modo en que efectivamente produzca un efecto contrario a la Constitución” (considerando 32).

Por todo eso en la sentencia rol No 815-08 el TC señaló que: "atendidos los efectos de la aplicación del precepto impugnado, no nos encontramos en ninguna de las situaciones en las cuales podría darse, eventualmente, una interpretación y aplicación conforme a la Constitución del precepto cuya constitucionalidad se cuestiona, de tal forma de poder dar eficacia al principio interpretativo de

26 Ver nota 6. 
conformidad de las normas a la Carta Fundamental, por el cual una norma será contraria a la Constitución sólo cuando no exista posibilidad alguna de comprenderla o darle eficacia dentro del marco de la misma" (considerando 34).

A su vez, y en la misma línea que la sentencia anterior, en el fallo rol No 99397 el Tribunal sostuvo que: "dentro del criterio de interpretación conforme a la Constitución, el respeto hacia las labores que desarrollan tanto el legislador al elaborar las normas de rango legislativo como la judicatura al aplicarlas, obliga al Tribunal Constitucional, en su función de contralor de la constitucionalidad de la ley, a buscar, al menos, alguna interpretación del precepto cuestionado que permita armonizarlo con la Carta Fundamental, y sólo en el evento de no ser ello posible, declarar su inconstitucionalidad, criterio que ha sido seguido en las sentencias roles 29, 38, 304, 368, 420, 460 y 681.

En sede de inaplicabilidad, también, en el caso concreto, 'es deber de esta Magistratura evitar que el precepto legal impugnado se interprete y aplique de un modo en que efectivamente produzca un efecto contrario a la Constitución"” (Sentencia Rol No 806) (considerando 50). Y agrega que "unido a ello, todo precepto legal que se impugne no constituye generalmente una norma aislada, sino que es un enunciado que, puesto en aplicación, guarda relaciones de interdependencia y operatividad con otros, a la luz de los cuales cabe ser interpretado y aplicado" (considerando $6^{\circ}$ ).

\section{B) El Tribunal Constitucional no tiene competencia para determinar cuál es la norma cuya aplicación prima en el marco de la resolución de la gestión pendiente}

No obstante lo señalado precedentemente, el Tribunal ha dejado en claro que existe un ámbito de interpretación que corresponde concretamente al juez de la gestión pendiente. De ahí que el Tribunal, en el marco del conocimiento de una acción de inaplicabilidad, no puede fijar un orden de prelación respecto de las normas llamadas a resolver un asunto determinado. En el evento que exista un concurso de normas, es decir, que dos o más normas puedan resultar idóneas para resolver el asunto sometido a conocimiento del juez ordinario, será éste quien deberá determinar la norma cuya aplicación resulta más idónea al caso concreto.

Así, el TC ha sido claro al señalar que no le atañe inmiscuirse en la labor misma de aplicación de las normas. Es decir, la determinación del precepto aplicable al caso concreto corresponde -en último término- al juez llamado 
a resolver la controversia. De este modo, la labor del TC queda circunscrita a determinar la sujeción, o no, de una norma al texto constitucional. Por eso ha sostenido que la determinación de si una o dos normas legales son aplicables a un caso es una cuestión que "incumbe realizar a la judicatura ordinaria y, por tanto, extraños a las atribuciones de esta Magistratura" (sentencia rol No 139009, considerando $12^{\circ}$ ).

En un sentido similar, en la sentencia rol No 1034-08 el TC señaló que la determinación de qué norma legal debe prevalecer en la resolución del caso concreto es una cuestión de legalidad, y que "su dilucidación no incumbe a esta Magistratura sino a los jueces del fondo, por lo que se omitirá pronunciamiento a su respecto" (considerando $\left.15^{\circ}\right)^{27}$.

Coherente con dicha posición, en la sentencia rol No 1340-09 el TC sostuvo que "ciertamente, no le corresponde a estos jueces constitucionales determinar si en la causa por investigación/reclamación de paternidad, caratulada "Muñoz con Muñoz", RIT C-111-2009, que sustancia actualmente el Juzgado de Familia de Pudahuel, y que constituye la gestión pendiente, concurren los supuestos necesarios para aplicar la regla de excepción contenida en el artículo 206 del Código Civil, pues ello es una labor que compete exclusivamente al juez del fondo" (considerando 15\%).

De esta forma, cada vez que la norma exija ciertos requisitos copulativos a modo de presupuesto de la acción que se entabla, no corresponderá al TC determinar si tales requisitos concurren o no. Por eso el TC ha señalado también que: "este Tribunal tampoco se involucrará en asuntos que impliquen definir la eventual contradicción entre dos preceptos legales. Ese es un asunto de legalidad porque implica definir cuál es la norma que debe ser aplicada preferentemente en la solución de un conflicto sometido a la jurisdicción. Para ello, es necesario convocar a criterios de interpretación legales, que resuelvan la antinomia entre normas de igual rango. Para las controversias legales, existen otras instancias jurisdiccionales y otros procedimientos" (sentencia rol No 1284-09, considerando 4o).

Este mismo criterio ha sido reiterado en la sentencia rol No 1352-09, en la que dejó en claro que no le correspondía resolver respecto de la "subsunción de la conducta al hecho incriminado por el legislador, que supone obligadamente la interpretación de la descripción típica, sin que pueda reprocharse por ello una contravención al artículo 19, No 3o de la Constitución. En otras palabras, si bien

27 En este mismo sentido sentencia rol No 1344-09, considerando décimo. 
el principio de legalidad impide al legislador describir indeterminadamente la conducta punible y, a su vez, le prohíbe al juez definirla, ello no descarta sino que supone la actividad judicial de determinar caso a caso si la conducta del imputado se ajusta al tipo penal. Lo razonado guarda coherencia con la jurisprudencia asentada por esta Magistratura en orden a que la aplicación de un precepto legal es de competencia del juez del fondo" (considerando $40^{\circ}$ ).

Más cercana en el tiempo es la sentencia rol No 2372-12 en la que el TC volvió a pronunciarse de similar manera al precisar que, "la determinación de qué norma legal debe prevalecer en una determinada gestión judicial es una decisión que no incumbe a esta Magistratura sino que a los jueces del fondo" (considerando $5^{\circ}$ ).

Por todo lo anterior, debe concluirse que una vez resuelto que la aplicación de un precepto legal no es contrario a la Constitución, es de exclusiva competencia del juez de la gestión resolver si lo aplicará o no. En tal sentido el TC ha sostenido que: "complementariamente a lo expresado, debe tenerse presente el efecto exclusivamente negativo de la declaración de inaplicabilidad. En efecto, si esta Magistratura decidiera que el precepto legal cuestionado es inaplicable en la gestión pendiente de que se trata, queda prohibido al tribunal que conoce de ella aplicarlo. En cambio, si se desecha la cuestión de inaplicabilidad deducida, al tribunal que conoce de la aludida gestión le asiste plenamente la facultad de determinar las normas que aplicará a la resolución del asunto", incluidas las que fueron impugnadas (sentencia rol No 784-07, considerando $14^{\circ}$ ).

En resumen, la labor del Tribunal sólo se limita a declarar si la posible aplicación de un precepto, acarrea consigo un resultado contrario a la Constitución. En este mismo orden de ideas, debemos señalar que el TC no está llamado a fijar un orden de prelación en la aplicación de las normas, sino que sólo puede determinar si la posible aplicación de una norma resulta o no contraria a la Constitución.

Por otra parte, la jurisprudencia demuestra que en aquellos casos en que puedan concurrir dos o más normas a la solución de un conflicto, alguna de las cuales puede resultar contraria al texto constitucional, nada impide que pueda promoverse la cuestión de inaplicabilidad ante el TC, en la medida que la norma cuestionada sea decisoria litis y se cumplan los demás requisitos de procedencia. En tal caso el Tribunal Constitucional podrá determinar que la aplicación de una de las normas que concurre a la resolución del asunto principal resulta contraria a la Constitución, pero no podrá señalar cuál de las que resultan acordes a ella debe ser preferida por el juez de la gestión. De este modo, el TC da cumplimiento de 
forma efectiva al mandato del constituyente en orden a pronunciarse exclusivamente sobre la constitucionalidad de la aplicación de una norma, y no sobre la primacía de un precepto legal sobre otro.

\section{C) No le corresponde al Tribunal Constitucional pronunciarse} sobre los efectos de la ley en cuanto al tiempo, por tratarse de un asunto de mera legalidad, aunque si es competente para pronunciarse sobre la vigencia de la Constitución en el tiempo

Un aspecto relacionado con el criterio anterior, es el relativo a la competencia para determinar cuál precepto legal debe primar cuando uno entró en vigencia con posterioridad a otro(s) y resultan incompatibles total o parcialmente entre sí. Se trata por tanto de determinar si el TC es o no competente para resolver sobre los efectos de las leyes en el tiempo. A este respecto el TC ha reconocido que los efectos de la ley, cuando éstos no se refieren a aspectos comprendidos en la órbita de sus atribuciones, corresponden exclusivamente al juez ordinario que conoce del asunto.

En tal sentido la sentencia rol No 503-06 constituye el fundamento de una doctrina que se ha consolidado en el tiempo ${ }^{28}$. En ella el TC sostuvo que la resolución de las cuestiones sobre sucesión de leyes en el tiempo "corresponde a los jueces del fondo; competencia que este Tribunal está obligado a respetar en virtud de lo dispuesto en el inciso segundo del artículo $7^{\circ}$ de la Constitución y en conformidad con el principio de deferencia razonada hacia los poderes del Estado" (considerando 9º). Y en la sentencia rol No 784-07 el TC aclaró que si resuelve que la aplicación del precepto legal impugnado no es contraria a la Constitución, "al tribunal que conoce de la aludida gestión le asiste plenamente la facultad de determinar las normas que aplicará a la resolución del asunto, sin que, necesariamente, hayan de ser aquellas cuya constitucionalidad se impugnó sin éxito ante este Tribunal, las que bien podría entender derogadas de acuerdo con sus propias competencias" (considerando $14^{\circ}$ ).

En todo caso, hay que precisar que en lo relativo al problema de la vigencia de la Constitución en el tiempo, la jurisprudencia del TC discurre por otros cauces. En principio debe considerarse que los jueces resuelven conflictos ju-

28 Esta doctrina ha sido reiterada por ejemplo en las sentencias roles 513-06, considerando 7o; 796-07, considerando $27^{\circ} ; 976-07$, considerando $16^{\circ} ; 1273-08$, considerando $40^{\circ} ; 1348-2009$, considerando $24^{\circ}$; 1532-09, considerando $7^{\circ}$. 
rídicos aplicando Derecho, y "una norma jurídica preconstitucional contraria a la Constitución no es Derecho, porque ha sido tácitamente derogada por ésta". Por eso en principio nada impide "que el juez de la instancia resuelva los problemas derivados de la pervivencia de una norma jurídica en el tiempo (ley o norma manifestación de potestad reglamentaria). Es decir, no existe obstáculo para que en los casos de que conocen los jueces se pronuncien respecto de los efectos temporales de la Constitución con relación a las normas jurídicas anteriores a ella" 29 . Esta facultad del juez puede desplegarse "cuando el demandado oponga como excepción o defensa la alegación de derogación tácita de la norma preconstitucional", o de oficio, "pues, el juez no puede resolver un juicio aplicando 'no Derecho"”30. Por ende, "todo juez de la República al enfrentarse a un caso como el descrito, debe optar por el criterio cronológico, prefiriendo a la Constitución como norma posterior, que al mismo tiempo es superior" 31 .

Sin embargo, desde la reforma de 2005 el TC "ha mantenido invariable su posición, referido a considerar que posee atribuciones para conocer del problema generado por leyes preconstitucionales", y que la competencia para aquello emana del artículo 93 № 632. Así, en la sentencia rol № 472-06 el TC sostuvo que, "debe tenerse presente que del texto del artículo 93 No 6 como del inciso undécimo de esa misma norma se desprende, inequívocamente, que la exigencia para que proceda un recurso de inaplicabilidad por inconstitucionalidad se refiere a que exista 'un precepto legal' cuya aplicación en cualquier gestión que se siga ante un tribunal ordinario o especial, resulte contraria a la Constitución, de lo cual se infiere que debe tratarse de un precepto legal que se encuentre vigente, con independencia de si dicha vigencia se produjo antes o después que la de la Carta Fundamental. Esta interpretación resulta ser la única que se concilia con el principio de supremacía constitucional consagrado en el artículo $6^{\circ}$, inciso primero de nuestro Código Político.

Por lo demás, la conclusión precedente resulta concordante con lo expresado por la Corte Suprema, en diversos fallos, cuando conociendo de requerimientos como los de la especie, ha afirmado que: "lo esencial para que esta Corte pueda pronunciarse sobre la inaplicabilidad de una ley radica en la condición de que

29 Martínez (2003), p. 727.

30 Ibid.

31 ROJAS (2013), p. 105.

32 Ibid., p. 104. 
ésta y la Carta Fundamental se hallen vigentes" (Sentencia de 20 de diciembre de 2002, rol No 3419-2001, considerando 8º)" (considerando 7o).

En otras palabras, y como destacan entre otros Navarro y Rojas para el TC la expresión "precepto legal" incluye normas legales anteriores y posteriores a la Constitución ${ }^{33}$. Por eso su competencia en materia de inaplicabilidad abarca a las normas preconstitucionales, en tanto en cuanto no hayan sido formalmente derogadas, de manera que si no consta su derogación, el TC entiende que el precepto debe considerarse vigente. Por el contrario, si hay derogación expresa (como la que se produciría en virtud del art. 94 inciso $3^{\circ}$ de la Constitución), no resulta procedente la inaplicabilidad, como lo declaró el TC en su sentencia rol No 1823-10 (considerando $6^{\circ}$ ).

Este criterio lo ha aplicado el TC en numerosas sentencias, y en todas ellas desechó las inaplicabilidades planteadas, ya que previamente el propio Tribunal, en uso de la atribución del art. 93 No 7 de la Constitución, había declarado inconstitucional algún precepto legal. Así sucedió con el artículo 116 del Código Tributario $^{34}$, y con el artículo 171 del Código Sanitario ${ }^{35}$, normas que por ende pasaron a entenderse derogadas, conforme a lo prescrito por el artículo 94 inciso $3^{\circ}$ de la Constitución ${ }^{36}$.

33 NAVARro (2011), p. 78; Rojas (2013), p. 109. La doctrina del TC respecto de su competencia para conocer de inaplicabilidades de preceptos legales preconstitucionales es compartida también por la doctrina, así por ejemplo ZúNIGa (2010), p. 16.

34 Declarado inconstitucional por la sentencia rol No 681-07. Con posterioridad a ella, el TC aplicó el criterio de que no procede la inaplicabilidad respecto de una norma legal declarada previamente inconstitucional por él mismo. Así ocurrió por ejemplo en numerosas sentencias de inaplicabilidad relativas al artículo 161 del Código Tributario. las sentencias roles Nos. 685-07, 987-07, 988-07, 989-07, 997-07, 998-07, 1012-07, 1013-07, 1014-07, 1042-08, 1043-08, 1044-08, 1045-08, 1136-08, 1137-08, 1231-08, 1232-08, 1386-09, $1395-09$ y $1396-09$, entre otras.

35 Declarado inconstitucional por la sentencia rol No 1345-09. Con posterioridad a ella, el TC aplicó también el criterio de que no procede la inaplicabilidad respecto de una norma legal declarada previamente inconstitucional en las sentencias roles $\mathrm{No}^{\circ}$. 1395-09, 1396-09, recaída en una cuestión de inaplicabilidad del artículo 171 del Código Sanitario.

36 Un interesante análisis crítico acerca de la aparente confusión del TC respecto de la validez y la eficacia de las normas, y su repercusión en las nociones de derogación expresa y tácita, puede consultarse en Rojas (2013), pp. 109 y ss. Como señala este autor, para el TC la inconstitucionalidad abarca tanto la derogación como la invalidez, lo que a su juicio no es correcto. No obstante, en la sentencia rol No 1552-09 señaló que la declaración de inconstitucionalidad del art. 93 No 7 de la Constitución significa las pérdida de vigencia del precepto legal más que de una derogación propiamente tal, la que sólo "se producirá en mérito de la dictación de otra ley, en tanto declaración de la voluntad soberana que proviene de los órganos legislativos". 
No obstante, el TC ha efectuado una interesante precisión con relación a los posibles efectos en el tiempo de un precepto legal que hubiere sido declarado inconstitucional, y que por ende se entiende como derogado. En efecto, en la sentencia rol No 1552-09 recordó que de acuerdo a la ley de efecto retroactivo de las leyes, "los efectos de una ley derogada pueden extenderse en el tiempo e invocarse por el solo hecho de formar parte de la relación contractual", lo que implica que la "ultractividad de la ley, entonces, tiene como fundamento no su valor normativo que se halla extinguido por la derogación, sino su presunto valor contractual al formar parte de la respectiva convención" (considerando $6^{\circ}$ ).

Pero a continuación el TC destaca que existe un límite a la libertad contractual en este ámbito, y que se relaciona con el efecto de sus sentencias de inconstitucionalidad. En concreto, el TC recuerda que ante la declaración de inconstitucionalidad el precepto legal se entiende derogado desde la publicación de la sentencia en el Diario Oficial, la que no producirá efecto retroactivo. Y si bien el propósito del Constituyente es "custodiar la seguridad jurídica y brindar protección a la apariencia generada al amparo de dicho precepto", a su vez "no es posible reconocer que los efectos de un precepto excluido del ordenamiento normativo, por contravenir lo ordenado en la Constitución, puedan invocarse en virtud de su incorporación a una relación contractual mientras aquél estuvo vigente" (considerando $8^{\circ}$ ).

El TC entendió en este caso que la declaración de inconstitucionalidad significa las pérdida de vigencia del precepto legal más que de una derogación propiamente tal, la que sólo "se producirá en mérito de la dictación de otra ley, en tanto declaración de la voluntad soberana que proviene de los órganos legislativos". Y a su vez "no parece posible que un precepto invalidado por esta Magistratura - puesto que la declaración de inconstitucionalidad lo priva de efectos desde la publicación de la sentencia respectiva en el Diario Oficial-pueda seguir rigiendo hacia el futuro bajo la premisa de haberse encontrado vigente al momento de perfeccionarse la antedicha relación contractual" (considerando 8º).

En consecuencia, "si una ley, por contravenir la Carta Fundamental, es excluida del ordenamiento jurídico, quedando, en consecuencia, invalidada, no puede subsistir tampoco en razón de una estipulación contractual, puesto que ella estaría afectada hacia el futuro del mismo vicio que motivó la declaración de inconstitucionalidad" (considerando 9º). De ahí que, "la expulsión del precepto legal del ordenamiento jurídico, en los términos referidos en la Constitución, importa una negación absoluta y definitiva de sus efectos, salvo de aquellos que la misma Constitución admite excepcionalmente por las razones ya expuestas". 
Y por tanto "[E]xtender dichos efectos más allá de lo expresamente previsto en la Carta Política (efecto ultractivo) importaría una evidente vulneración de su sentido y espíritu y una clara limitación a los fines previstos en la misma Constitución, sobrepasándola" (considerando $\left.10^{\circ}\right)^{37}$.

\section{D) No le corresponde al Tribunal pronunciarse sobre aspectos valorativos relativos a los hechos litigiosos, a menos que ello permita acreditar la vulneración de derechos fundamentales}

Como se sabe, en un juicio hay hechos y aspectos relacionados con el asunto controvertido que deben ser determinados, analizados y valorados por el juez que conoce del asunto principal. $\mathrm{Al}$ respecto el TC ha declarado que aquello es privativo de la justicia ordinaria, de modo que la justicia constitucional no puede transformarse en un medio paralelo de resolución de la controversia principal. Por eso ha sostenido que: "no puede emitir un pronunciamiento valorativo sobre hechos litigiosos de la gestión pendiente, cuyo establecimiento pareciera ser clave para la resolución del asunto, específicamente si la sentencia está cumplida o no. Cabe señalar que la ponderación de los mismos corresponde a los jueces del fondo, por ser, también, un tema de legalidad ordinario y estar dentro de su competencia relativa a la gestión, no correspondiendo que esta Magistratura los pondere" (sentencia rol No 1273-2008, considerando 21\%) 38 .

Asimismo, en las sentencias roles $\mathrm{No}^{\text {s. }}$ 1212-08 y 2350-12 el TC señaló que "la subsunción de las circunstancias de hecho del caso particular dentro de lo dispuesto en el precepto es tarea propia del juez del fondo, al igual que la interpretación de sus términos" (considerandos $11^{\circ}$ y $1^{\circ}$, respectivamente). Y en la sentencia rol No 2561-13 sostuvo que, "si se realizaron o no las investigaciones correspondientes, como requisito para comunicar la decisión de no perseverar, es una decisión que corresponde al juez del fondo", y que cuando está "controvertida la existencia de diligencias pendientes, hay un problema de legalidad involucrado, toda vez que sólo cerrada la investigación, por haberse practicado las diligencias necesarias para la averiguación del hecho punible, cabe que el

\footnotetext{
37 Esta sentencia se contrapone a otras en las que el TC entendió que la declaración de inconstitucionalidad del art. 93 No 7 tiene efecto derogatorio, y que por ende no procede la cuestión de inaplicabilidad respecto de los preceptos legales declarados inconstitucionales. Vid. notas 35, 36 y 37.

38 Este mismo criterio ha sido reiterado, por ejemplo, en las sentencias roles $\mathrm{No}^{\circ}$. 1130-08, 1210-08, 1266-08 y $1324-09$.
} 
Ministerio Público comunique su decisión de no perseverar". Ello constituye "un asunto de interpretación de supuestos de la aplicación de normas, más que una contradicción del precepto impugnado con la Carta Fundamental", lo que no es de competencia del TC (considerando $5^{\circ}$ ).

Más recientemente, y a modo de resumen de este criterio, el TC ha planteado con claridad que, "[L]a comprobación de la concurrencia de los supuestos de la norma, es tarea del juez", y que "[R]ecabar de la ley -general y abstracta- omnicomprensión de todas las circunstancias posibles, no es compatible con el método jurídico" (sentencia rol No 2670-14, considerando $7^{\circ}$ ).

No obstante todo lo anterior, en su jurisprudencia más reciente el TC ha señalado una importante excepción, que matiza en cierta forma los pronunciamientos anteriores, y que se relaciona con el hecho de que la cuestión de inaplicabilidad implica muchas veces una tutela indirecta de derechos fundamentales. Así, en la sentencia rol No 2538-13 el TC ha sostenido que, "ejerciéndose la cuestión de inaplicabilidad sobre un precepto legal cuya aplicación en cualquier gestión que se siga ante un tribunal ordinario o especial, resulte contraria a la Constitución”, y siempre que dicha aplicación del referido precepto legal puede resultar decisiva en la resolución del asunto, es permitido a este órgano de justicia constitucional "practicar un examen concreto de si el precepto legal, invocado en una gestión judicial y correctamente interpretado producirá efectos o resultados contrarios a la Constitución”. En ese examen, el Tribunal es competente para ponderar una cuestión de hecho, si de ello depende la acreditación de la vulneración al derecho fundamental que los requirentes estiman infringido, pero con dos límites: a) No le corresponde "establecer el sentido y alcance de las normas jurídicas sino cuando ellas resulten necesarias para resolver las controversias que se le plantean" y b) "carece de competencia y jurisdicción para resolver cuestiones de mera legalidad, que deberán ser resueltas por los jueces del fondo" (considerando duodécimo).

\section{E) Los aspectos procesales referentes a la litis han de ser resueltos por el juez que conoce del asunto controvertido}

Otro criterio interesante acuñado por el TC es el relativo a las normas de procedimiento aplicables en la gestión pendiente. En ese sentido, el TC ha manifestado nuevamente su deferencia con los tribunales a cargo de la gestión en que incide la inaplicabilidad, y en consecuencia ha sostenido que la determinación de cuáles normas procesales deben aplicarse es de resorte de ellos. En concreto, en la sentencia rol No 2014-11 el TC indicó que, "no le corresponde calificar al 
Tribunal Constitucional las reglas procesales, la carga de la prueba, las facultades del juez o las garantías que se derivan de aplicar uno u otro procedimiento legal. Parte de la deferencia de esta Magistratura con el juez de fondo, es preservar dicha definición a la jurisdicción laboral y de derecho común concernida, respectivamente" (considerando 6o).

En este caso, no solamente se manifiesta una deferencia hacia el propio juez, sino también respecto del legislador, ya que ha sido éste el que fija los diversos procedimientos que sirven para la resolución de conflictos. Y en tal sentido, la inobservancia de las reglas que rigen tales procedimientos puede impugnarse a través de los mecanismos y recursos que el propio legislador ha determinado, los que deben ser resueltos por el mismo juez ante el cual se sustancia el asunto, o ante el juez ad quem en su caso.

\section{F) Los aspectos relativos a la recta interpretación de la ley deben ser resueltos por el juez de fondo}

Este criterio es probablemente uno de los más utilizados por el TC con el objeto de rechazar cuestiones de inaplicabilidad. Y es que en términos generales la interpretación de la ley no es parte de sus atribuciones, sino que se trata de una materia que corresponde privativamente al juez llamado a fallar el juicio o gestión pendiente. En palabras de Navarro Beltrán, la inaplicabilidad "no es la vía para aclarar el sentido de preceptos legales" 39 .

Es por eso que el TC ha indicado que la labor de unificar la interpretación sobre un precepto legal le corresponde a la Corte Suprema. Así, en la sentencia rol No 810-07 se señala que: "si bien, entre las reseñadas características de la actual acción de inaplicabilidad por inconstitucionalidad, resalta la que indica que mientras antes se trataba de una confrontación abstracta entre la norma legal cuestionada y una disposición constitucional, ahora se trata de un cotejo entre la aplicación del precepto legal impugnado a un caso concreto y la Constitución, no debe perderse de vista que, tanto antes como ahora, para que la acción pueda prosperar, debe estarse siempre en presencia de un conflicto de constitucionalidad, esto es, frente a una contradicción directa, clara y precisa, entre determinado precepto legal que se pretende aplicar en el caso concreto, con la propia Constitución, pues el juez constitucional no puede interpretar o

39 NAVArro (2011), p. 71. 
corregir la ley ordinaria si no es con relación a su constitucionalidad. La tarea de interpretar la ley le corresponde a los tribunales de justicia, sean ordinarios o especiales, y, en nuestro sistema judicial, el órgano llamado a unificar su interpretación es la Corte Suprema, a través del recurso de casación. La labor del Tribunal Constitucional consiste en velar por el respeto del principio de supremacía constitucional y, por ende, tratándose de una acción de esta clase, resolver si la aplicación en el caso concreto de que se trate del precepto legal impugnado, resulta o no contraria a la Carta Fundamental y, como efecto natural de una decisión estimatoria, prohibir al juez de la causa aplicarlo en la resolución de ese caso concreto" (considerando $\left.9^{\circ}\right)^{40}$.

Como consecuencia de lo anterior, la inaplicabilidad no puede utilizarse como un mecanismo de impugnación de la interpretación que hizo el juez de un precepto legal cuya aplicación no es contraria a la Constitución. En tal sentido no le corresponde al TC "la determinación de la ley sustantiva del caso", ya que la interpretación y aplicación de normas legales le "corresponde a los tribunales establecidos por la ley" (sentencia rol No 986-07, considerando 24\%). Por ende "no es de su esfera competencial el resolver acerca de la eventual aplicación incorrecta o abusiva de un determinado precepto legal que pudiere efectuar un tribunal, lo que corresponderá corregir, en su caso, a través de los recursos que contemplan las leyes de procedimiento" (sentencia rol No 1416-09, considerando 19\%).

En resumen, y como lo ha indicado expresamente el TC, no es de su competencia determinar con qué sentido y alcance deben ser entendidas las normas aplicables en el asunto del que conoce el juez ordinario o especial (sentencias roles Nos. 980-07, considerando 8º y 1390-09, considerando $\left.12^{\circ}\right)^{41}$.

40 Las normas que el recurrente entendía infringidas eran los números 2 y 20 del artículo 19, es decir, la igualdad ante la ley y la igualdad ante las cargas públicas. Son varios los problemas que se derivan de la posición adoptada en este caso por el Tribunal. En primer lugar, el más obvio, es que el Tribunal se apartó de una doctrina que venía siendo una constante desde 2006. Y lo que es peor, lo hizo contradiciéndose abiertamente, al dar por sentado que no está facultado para controlar la interpretación de la ley hecha por un tribunal Tributario. Con ello dio a entender que se trataba de un problema de mera legalidad, y no de constitucionalidad, cuando en verdad lo que ocurría era que debía enjuiciar la forma en que aquél entendió y aplicó normas sustantivas de Derecho de familia y de Derecho tributario, y si ello era o no compatible con la Constitución. Este solo hecho transforma el conflicto en algo más que un mero problema de interpretación de la ley, pasando a ser uno de constitucionalidad.

Por eso la posición del Tribunal en esta materia no fue la más afortunada, al no haber entrado al enjuiciamiento de fondo, y pronunciarse por ende respecto de las infracciones que el recurrente le imputaba al juez tributario.

41 Este mismo criterio lo encontramos presente en otras sentencias del Tribunal Constitucional, como por ejemplo en las sentencias roles $\mathrm{No}_{\text {s. }}$ 1454-09, 1453-09, 1781-10, 1432-09, 1443-09, 1839-10, 1832-10, 
G) No corresponde al Tribunal Constitucional ejercer el control de inaplicabilidad de un precepto legal, si es que la vulneración al texto de la Carta Magna sólo podría tener lugar al momento de dictación del fallo, o en una causa futura e incierta

Al analizar el problema de la inaplicabilidad como mecanismo de control de la interpretación y aplicación de preceptos legales, señalamos que la inaplicabilidad conduce a controlar la constitucionalidad de las interpretaciones de preceptos legales aplicables a la gestión pendiente. Ello resulta especialmente importante cuando el precepto puede ser considerado constitucional si se le interpreta de determinada manera. Así ocurre en los casos en que hay una gestión en la que aún no se ha aplicado el precepto legal, como en los que sí se ha aplicado y está pendiente aún la resolución de recursos procesales. En esta situación la cuestión funciona como un instrumento de control preventivo, en el sentido de que permitirá que el precepto legal se aplique sólo si aquello es conforme a la Constitución. En estos supuestos el TC controlará las diversas interpretaciones posibles que puedan dársele a un precepto legal, pero sólo a fin de descartar aquéllas que puedan ser opuestas a la Constitución. Por ende, y en teoría, la declaración de inaplicabilidad podría pronunciarse antes de que se dicte sentencia por el tribunal de la gestión.

Sin embargo, el TC ha efectuado algunas precisiones que matizan las anteriores afirmaciones. Así, ha sostenido que no le corresponde ejercer un control sobre potenciales o eventuales vulneraciones al texto constitucional, y que por tanto la inaplicabilidad no es una vía abierta para tal fin. Por eso en la sentencia rol No 1445-09 el TC constató que: "en el caso concreto en que se ha solicitado pronunciamiento de inaplicabilidad, los preceptos impugnados no tienen una posibilidad real de ser aplicados y ser decisivos, sino tan sólo una posibilidad hipotética y teórica, y es menester diferenciar estas situaciones, por cuanto la segunda de ellas no amerita un pronunciamiento de este sentenciador, desde el momento en que no ha sido llamado a emitir pronunciamientos de inaplicabilidad de eficacia hipotética" (considerando 36 $6^{\circ}$.

Más recientemente, en la sentencia rol No 2651-14, el TC ha vuelto a sostener que "no cabe declarar inaplicable un precepto en virtud de un efecto contrario

1860-10, 1615-10, 1853-10, 2011-11, 2072-11, 1892-11, 2193-12, 2178-12, 2150-11, 1995-11, 2208-12, 1968-11, 2184-12, 2220-12, 2248-12, 2318-12, 2326-12, 2359-12, 2360-12, 2225-12, 2400-13, 2418-13, 2459-13, 2450-13, 2473-13, 2741-14. 
a la Carta Fundamental que éste puede producir teóricamente o en una causa futura e incierta, sino solo por aquel que tiene la posibilidad de verificarse en la gestión pendiente" (considerando $11^{\circ}$ ).

La posición del TC en esta materia resulta discutible, ya que como se vio recién, los objetivos y estructura de la inaplicabilidad hacen perfectamente posible que ésta opere como un control preventivo de posibles aplicaciones inconstitucionales. Por lo demás, y como se ha analizado en este trabajo, en varias oportunidades el TC ha aplicado en sede de inaplicabilidad el criterio de interpretación conforme, la que puede desplegarse tanto en el caso de no haber aún sentencia alguna en el caso sub lite, o habiéndola, están pendientes los recursos legales en su contra.

\section{H) La recta interpretación de los tratados es una cuestión de legalidad que debe resolverse por los jueces del fondo}

Otra temática interesante resuelta por el TC, es la relativa a la aplicación de tratados internacionales en gestiones seguidas ante un tribunal ordinario o especial. En consistencia con su propia doctrina sobre el lugar que los tratados ocupan en el sistema de fuentes del Derecho chileno, el TC ha sostenido que la interpretación de ellos es de competencia de los jueces ante quienes se siguen tales gestiones. Así, en la sentencia rol No 1220-08 el TC sostuvo que, "el requerimiento no cumple con el presupuesto procesal establecido para su admisión a trámite por la Carta Fundamental, toda vez que se dirige en contra de un conflicto de legalidad, surgido en la causa rol No 168-2008, juicio laboral seguido ante el Quinto Juzgado Laboral de Santiago caratulado "Moscoso con Consejo de las Américas"; lo que debe ser resuelto por el tribunal de la instancia, situación que en definitiva constituye una cuestión de recta interpretación de la ley y de los tratados internacionales, materia que no se encuentra dentro del marco de atribuciones de este órgano de jurisdicción constitucional. Por las razones expuestas, esta Sala decidirá que no concurre el presupuesto" (considerando $8^{\circ}$ ).

La misma idea fue recogida nuevamente por el TC en la sentencia rol No 1230 08 en la que dijo que, "es menester señalar que, según el criterio sostenido por la jurisprudencia de esta Magistratura, las argumentaciones reseñadas en el considerando precedente no pueden ser abordadas ni resueltas por este órgano jurisdiccional, atendido que, por decir relación con cuestiones de mera legalidad y de interpretación de una norma legal, no son propias del examen de constitucionalidad que procede efectuar en sede de inaplicabilidad, sino más bien deben ser resueltas por los jueces de la instancia" (considerando 61\%). 
En todo caso, no obstante la competencia de los jueces de la gestión pendiente para determinar el sentido y alcance de los tratados internacionales, en esta labor deberán considerar una regla básica enunciada por el Tribunal Constitucional en su sentencia rol No 309. En ella el TC sostuvo que: "el intérprete debe hacer todos los esfuerzos, dentro de lo permitido por la Ley Suprema del respectivo Estado, por encontrar una interpretación conciliatoria entre las normas de un Tratado y los preceptos de la Constitución" (considerando 30)". Ello es consecuencia del principio de "interpretación conforme", desarrollado por el Tribunal como mecanismo de deferencia hacia el legislador, según se expuso antes.

\section{CONCLUSIONES}

A partir de la reforma constitucional de 2005, la inaplicabilidad pasó a ser un mecanismo de control concreto de constitucionalidad, que permite determinar si la aplicación de preceptos legales en casos concretos puede ser o no contraria a la Constitución. Necesariamente ello implica determinar si aquéllos tienen sentidos

y alcances compatibles con la Carta Fundamental, porque la aplicación de una norma supone necesariamente su previa interpretación.

Sin embargo, el principio de juridicidad impone a los poderes del Estado el deber de actuar "dentro de sus competencias", lo que determina que el TC debe respetar las que son propias de los otros órganos, incluidos los tribunales ordinarios y especiales. Para tal efecto el TC aplica la deferencia y la auto restricción, para lo cual ha elaborado una serie de criterios aplicables respecto del juez de la gestión, entre los que se cuentan los siguientes:

1. La "interpretación conforme" sólo se restringe a descartar interpretaciones inconstitucionales.

2. El TC no tiene competencia para determinar cuál es la norma cuya aplicación prima en el marco de la resolución de la gestión pendiente.

3. No le corresponde al TC pronunciarse sobre los efectos de la ley en cuanto al tiempo, por tratarse de un asunto de mera legalidad, aunque sí es competente para pronunciarse sobre la vigencia de la Constitución en el tiempo.

4. No le corresponde al Tribunal pronunciarse sobre aspectos valorativos relativos a los hechos litigiosos, a menos que ello permita acreditar la vulneración de derechos fundamentales.

5. Los aspectos procesales referentes a la litis han de ser resueltos por el juez que conoce del asunto controvertido.

6. Los aspectos relativos a la recta interpretación de la ley deben ser resueltos por el juez de fondo. 
7. No corresponde al Tribunal Constitucional ejercer el control de inaplicabilidad de un precepto legal, si es que la vulneración al texto de la Carta Magna sólo podría tener lugar al momento de dictación del fallo, o en una causa futura e incierta.

8. La recta interpretación de los tratados es una cuestión de legalidad que debe resolverse por los jueces del fondo.

Dichos criterios son una buena muestra del esfuerzo que ha efectuado el TC por no invadir las competencias propias de los tribunales ordinarios y especiales, ante los que se ventilan las gestiones pendientes en que se plantearon cuestiones de inaplicabilidad. Pero este esfuerzo muestra también algunas confusiones, como por ejemplo una cierta falta de claridad respecto de los conceptos de derogación (expresa y tácita) y de declaración de inconstitucionalidad, según se vio a lo largo de estas páginas.

\section{BiBLIOGRAFÍA}

Aldunate Lizana, Eduardo (2009): Jurisprudencia constitucional 2006-2009. Estudio selectivo (Santiago, LegalPublishing).

BerTelsen RePETto, Raúl (1999): “Análisis y revisión del recurso de inaplicabilidad (Modelo y Jurisprudencia)”, 159-179, en GÓmEz Bernales, Gastón (Editor): La jurisdicción constitucional chilena ante la reforma (Santiago, Cuadernos de Análisis Jurídico 41, Escuela de Derecho, Universidad Diego Portales, 1999).

Betti, Emilio (2009): La interpretación jurídica (Santiago, Legal Publishing).

Couso Salas, Javier y Coddou MacManus, Alberto (2010): "La naturaleza jurídica de la acción de inaplicabilidad en la jurisprudencia del Tribunal Constitucional: un desafío pendiente", en Estudios Constitucionales, año 8, No 2, 389-430.

Favoreu, Louis (1994): Los tribunales constitucionales (Barcelona, Ariel).

Gómez Bernales, Gastón (2005): "La reforma constitucional a la jurisdicción constitucional”, en ZúNiga URBINA, Francisco (Editor), Reforma constitucional, 651-684 (Santiago, LexisNexis).

Hormazábal Malarée, Hernán (2006): El nuevo Tribunal Constitucional. Los derechos fundamentales y el moderno recurso de inaplicabilidad (Santiago, LexisNexis).

Kelsen, Hans (1973): Teoría pura del Derecho (Buenos Aires, Editorial Universitaria, $11^{a}$ edición). 
Martínez Estay, José Ignacio: "El juez y los efectos de la constitución en el tiempo", en Revista de Estudios Constitucionales, Vol. 1, No 1, 2003, pp. 715-737. , (2011): "La cuestión de inaplicabilidad como mecanismo de control de la interpretación de preceptos legales", en Arancibia Mattar, Martínez Estay y Romero Seguel (Coordinadores), Litigación pública, pp. 377-396 (Santiago, AbeledoPerrot-Thomson Reuters).

, "Auto-restricción, deferencia y margen de apreciación. Breve análisis de sus orígenes y de su desarrollo", en Estudios Constitucionales, Año 12, No 1, 2014, pp. 365-396.

Navarro Beltrán, Enrique (2011): "El control de constitucionalidad de las leyes en Chile (1811-2011)", Cuadernos del Tribunal Constitucional No 43.

NúNez Poblete, Manuel (2010): "Sobre la declaración de inaplicabilidad de los tratados internacionales. Un estudio en defensa de su fundamento y legitimidad", en Estudios Constitucionales, Año 8, No 2, pp. 431-464.

Rojas Chamaca, Julio César (2013): La derogación tácita de preceptos preconstitucionales por la jurisdicción ordinaria: análisis de la jurisprudencia después de la reforma constitucional de 2005 (Santiago, Editorial Metropolitana).

Zapata Larraín, Patricio (2008): Justicia Constitucional. Teoría y práctica en el Derecho chileno y comparado (Santiago, Editorial Jurídica de Chile).

ZúNiga Urbina, Francisco (2010): Acciones de inaplicabilidad e inconstitucionalidad. Doctrina y jurisprudencia del Tribunal Constitucional sobre temas procesales (Santiago, AbeledoPerrot).

\section{LISTADO DE SENTENCIAS DEL TC CITADAS}

Rol No 472-06, de 30 de agosto de 2008.

Rol No 473-06, de 8 de mayo de 2007.

Rol No 478-06, de 8 de agosto de 2006.

Rol No 480-06, de 27 de junio de 2006.

Rol No 503-06, de 19 de julio de 2006.

Rol No 513-06, de 2 de enero de 2007.

Rol No 517-06, de 8 de mayo de 2007.

Rol No 535-06, de 8 de mayo de 2007.

Rol No 596-06, de 12 de julio de 2007.

Rol No 634-06, de 9 de agosto de 2007.

Rol No 681-07, de 26 de marzo de 2007. 
Rol No 685-07, de 17 de enero de 2008.

Rol No 784-07, de 10 de diciembre de 2007.

Rol No 791-07, de 15 de enero de 2008.

Rol No 796-07, de 11 de diciembre de 2007.

Rol No 806-07, de 11 de diciembre de 2007.

Rol No 810-10, de 24 de enero de 2008.

Rol No 815-08, de 19 de agosto de 2008.

Rol No 967-07, de 19 de diciembre de 2007.

Rol No 968-07, de 10 de julio de 2008.

Rol No 976-07, de 26 de junio de 2008.

Rol No 980-07, de 13 de mayo de 2008.

Rol No 986-07, de 30 de enero de 2008.

Rol No 987-07, de 22 de julio de 2008.

Rol No 988-07, de 22 de julio de 2008.

Rol No 989-07, de 22 de julio de 2008.

Rol No 993-07 de 13 de mayo de 2008.

Rol No 997-07, de 22 de julio de 2008.

Rol No 998-07, de 22 de julio de 2008.

Rol No 1012-07, de 22 de julio de 2008.

Rol No 1013-07, de 22 de julio de 2008.

Rol No 1014-07, de 8 de julio de 2008.

Rol No 1034-08, de 7 de octubre de 2008.

Rol No 1042-08, de 22 de julio de 2008.

Rol No 1043-08, de 22 de julio de 2008.

Rol No 1044-08, de 22 de julio de 2008.

Rol No 1045-08, de 22 de julio de 2008.

Rol No 1130-08, de 7 de octubre de 2008.

Rol No 1136-08, de 24 de julio de 2008.

Rol No 1137-08, de 24 de julio de 2008.

Rol No 1210-08, de 11 de septiembre de 2008.

Rol No 1212-08, de 22 de septiembre de 2008.

Rol No 1220-08, de 16 de septiembre de 2008.

Rol No 1230-08, de 2 de junio de 2009.

Rol No 1231-08, de 9 de junio de 2009. 
Rol No 1232-08, de 9 de junio de 2009.

Rol No 1266-08, de 29 de enero de 2009.

Rol No 1273-08, de 24 de abril de 2010.

Rol No 1284-09, de 24 de septiembre de 2009.

Rol No 1324-09, de 12 de febrero de 2009.

Rol No 1344-09, de 26 de marzo de 2009.

Rol No 1345-09, de 25 de mayo de 2009.

Rol No 1340-09, de 29 de septiembre de 2009.

Rol No 1348-09, de 27 de abril de 2010.

Rol No 1352-09, de 20 de mayo de 2010.

Rol No 1386-09, de 1 de julio de 2009.

Rol No 1395-09, de 25 de junio de 2009.

Rol No 1390-09, de ocho de abril de 2010.

Rol No 1396-09, de 25 de junio de 2009.

Rol No 1416-09, de 14 de julio de 2009.

Rol No 1432-09, de 5 de agosto de 2010.

Rol No 1443-09, de 26 de agosto de 2010.

Rol No 1445-09, de 29 de enero de 2010.

Rol No 1453-09, de 20 de julio de 2010.

Rol No 1454-09, de 20 de julio de 2010.

Rol No 1552-09, de 28 de octubre de 2010.

Rol No 1615-10, de 20 de enero de 2011.

Rol No 1781-10, de 5 de agosto de 2010.

Rol No 1823-10, de 22 de septiembre de 2010.

Rol No 1832-10, de 17 de noviembre de 2010.

Rol No 1839-10, de 28 de octubre de 2010.

Rol No 1853-10, de 24 de marzo de 2011.

Rol No 1860-10, de 7 de diciembre de 2010.

Rol No 1892-11, de 17 de noviembre de 2011.

Rol No 1968-11, de 15 de mayo de 2012.

Rol No 1995-11, de 26 de abril de 2010.

Rol No 2011-11, de 26 de julio de 2011.

Rol No 2014-11, de 6 de noviembre de 2012.

Rol No 2072-11, de 25 de octubre de 2011. 
Rol No 2150-11, de 4 de abril de 2012.

Rol No 2178-12, de 3 de abril de 2012.

Rol No 2184-12, de 5 de junio de 2012.

Rol No 2193-12, de 27 de marzo de 2012.

Rol No 2208-12, de 4 de abril de 2012.

Rol No 2220-12, de 21 de junio de 2012.

Rol No 2225-12, de 8 de enero de 2013.

Rol No 2248-12, de 25 de julio de 2012.

Rol No 2318-12, de 13 de noviembre de 2012.

Rol No 2326-12, de 11 de diciembre de 2012.

Rol No 2350-12, de 28 de mayo de 2013.

Rol No 2359-12, de 2 de enero de 2013.

Rol No 2360-12, de 2 de enero de 2013.

Rol No 2372-12, de 4 de noviembre de 2014.

Rol No 2538-13, de 9 de septiembre de 2014.

Rol No 2400-13, de 31 de enero de 2013.

Rol No 2418-13, de 15 de marzo de 2013.

Rol No 2450-13, de 28 de mayo de 2013.

Rol No 2459-13, de 16 de mayo de 2013.

Rol No 2561-13, de 30 de diciembre de 2014.

Rol No 2670-14, de 2 de diciembre de 2014.

Rol No 2473-13, de 23 de julio de 2013.

Rol No 2741-14, de 18 de diciembre de 2014 